\title{
Studies in Australian Epacridaceae: Changes to Styphelia
}

\author{
J.M. Powell, G. Robertson, B.M. Wiecek and J.A. Scott
}

\begin{abstract}
J.M. Powell, G. Robertson, B.M. Wiecek and J.A. Scott (National Herbarium of New South Wales, Royal Botanic Gardens, Sydney, NSW, Australia 2000) 1992. Studies in Australian Epacridaceae: Changes to Styphelia. Telopea 5(1): 207-227. Two new species are described: Styphelia psiloclada J. Powell and S. perileuca J. Powell and variation within S. laeta and S. viridis studied. Two subspecies are recognised within $S$. laeta (subsp. laeta and subsp. latifolia (R. Br.) J. Powell, based on S. latifolia R. Br.) and var. angustifolia (DC.) Benth. is reinstated at species level as S. angustifolia DC. Within S. viridis two subspecies are recognised: subsp. viridis and subsp. breviflora (Benth.) J. Powell, based on S. viridis Andr. var. breviflora Benth. Notes on the nomenclature, types, distribution and ecology are given.
\end{abstract}

\section{Introduction}

Currently in Australia the genus Styphelia is accepted in the strict sense, as defined by Robert Brown (1810) rather than in the wider interpretation of F. Mueller $(1867,1889)$. It comprises 12 endemic species (possibly 18 taxa) and is found in all States except the Northern Territory.

The genus is distinguished from other members of the tribe Styphelieae in having revolute corolla lobes, filiform filaments and well-exserted versatile anthers. All Styphelia species are shrubby, and all have an erect to spreading habit except $S$. adscendens, which is decumbent. The flowering shoots are auxotelic, the flowers usually solitary with a bract-like rudiment of a second, or rarely two together on a short peduncle. The corolla has a cylindrical tube, hairy inside at the throat and either glabrous or with fine tufts of hair below the middle; the lobes are linear and bearded inside with ornamented hairs. The anthers are free, linear, attached at their midpoint to the filiform filaments that are inserted in the throat. The ovary is five-locular, the style filiform and longer than the corolla tube, the stigma small, lobed; the nectary is annular or in distinct scales. The mesocarp of the fruit can be dry or fleshy, the endocarp always hard and bony.

Bentham (1869) distinguished two sections within the genus on the basis of corolla hair distribution, namely Eustyphelia (equivalent to section Styphelia), having the corolla-tube with five dense tufts of hair below the middle, sometimes confluent in a ring, and Soleniscia, with the corolla-tube glabrous inside except for a few hairs in the throat. In New South Wales nine taxa within six species were described by Bentham (1869), all belonging to section Styphelia.

Study of collections held at the National Herbarium of New South Wales undertaken while preparing a treatment for the Flora of New South Wales indicated the presence of two new species and that re-assessment of the status of taxa within Styphelia laeta and S. viridis was needed. 


\section{Methods}

Characters traditionally used in distinguishing taxa within Styphelia include leaf shape, surface flatness, leaf margin type and to a lesser extent leaf colour, apex shape, branch hairiness and habit and flower position. These characters were studied together with others, found also to be of value in distinguishing some taxa: leaf size, ratio of leaf length: width, leaf base shape, petiole length, numbers of flowers per inflorescence, bracteole and sepal size, sepal apex shape, corolla tube and lobe length, and the length of the anther and filament. Scanning electron microscopy of branchlet and leaf surfaces, of leaf margins and apices, and of corolla hairs and pollen was also used to provide additional and more detailed information.

In studying variation within each of $S$. laeta and $S$. viridis respectively, ranges of qualitative and quantitative attributes were tabulated, and polygonal graphs of the main discriminatory attributes drawn for the $S$. laeta taxa, to provide a preliminary assessment of the overall similarity of the taxa within each species.

Additionally, the main quantitative attributes were examined using the PATN package (pattern analysis, Belbin 1989a, b). A hierarchical classification was produced using the Gower Metric association measure together with UPGMA (FUSE program). The Gower Metric association measure was chosen as the most appropriate for continuous taxonomic data as it has the advantage of range standardization. The groupings displayed in the dendrogram (DEND) were defined using the group definition program GDEF and the attributes most responsible for forming the groups were determined using the GSTA program.

Ordination of the data was carried out using the SSH multidimensional scaling on the Gower metric association matrix and displayed as a scatter diagram (SCAT program). The principal correlation axes were derived using the PCC routine. These indicate how well the attributes relate to the ordination.

\section{Results and Discussion}

\section{The new species}

Specimens of the two new species had been included in S. triflora, or in S. viridis, since some of their leaf and floral characters are similar to one or other of these taxa, or intermediate between them. The main characters separating the two new species from S. triflora and S. viridis are given in Table 1.

S. psiloclada is similar to S. triflora in having glabrous branchlets and the leaf margins entire; the corollas and anthers of the two species are also of similar size. It differs, however, in leaf shape (being more like $S$. viridis), and in having shorter petioles and sepals. S. perileuca, on the other hand, is more distinct. The branchlet indumentum is of stiff hairs rather than soft (as in S. viridis), and the leaves are shorter than in either $S$. triflora or $S$. viridis. The flower colour may parallel some $S$. triflora populations but in flower size $S$. perileuca is at the lower end of the range of $S$. triflora. The leaves of both new species are convex adaxially while in $S$. triflora the leaves are usually concave adaxially. The habitats and distributions of the two new species as currently known also differ from $S$. triflora but, as the latter is the most widespread and variable species within Styphelia, further study of its populations is warranted. The new taxa are being recognised at the species level as they are morphologically distinct in a number of attributes or in the combination of attributes shown. 
Table 1. Comparison of attributes of S. triflora and S. viridis with the two new taxa

\section{Character}

Branchlet indumentum

Leaf shape

Leaf-blade length $(\mathrm{mm})$

Leaf-blade width ( $\mathrm{mm}$ )

Leaf apex

Leaf base

Leaf indumentum

Leaf margin

Lamina in T.S.

Petiole length $(\mathrm{mm}$

Flower position

Flower no./inflorescence

Flower colour

Peduncle indumentum

Sepal length $(\mathrm{mm})$

Sepal apex

Sepal indumentum

Corolla-tube length ( $\mathrm{mm}$ )

Corolla-lobe length $(\mathrm{mm})$

Anther length ( $\mathrm{mm}$ )

Filament length (mm)

\section{S. triflora}

glabrous

elliptic to oblong-elliptic

$$
\begin{gathered}
\text { 14-33 } \\
\text { 3-8.3 } \\
\text { acute } \\
\text { cuneate } \\
\text { glabrous } \\
\text { entire }
\end{gathered}
$$

flat to concave

$$
\text { 2-4 }
$$

spreading to pendant

1-3

pink to red, cream or pale yellow-green

$\begin{array}{cc}\text { glabrous } & \text { pubescent } \\ 8.2-13.4 & 12.7-16 \\ \pm \text { obtuse } & \text { acute to broadly so } \\ \text { glabrous } & \text { glabrous to puberulent } \\ & \text { near apex }\end{array}$

13-29.4

12.5-18

3-5

9-17.2

\section{S. viridis}

puberulent

oblong to oblong-obovate or oblong-elliptic

$$
\begin{gathered}
14.8-25.6 \\
2.9-7.2
\end{gathered}
$$

more or less obtuse

obtuse or \pm cuneate

glabrous

denticulate-ciliolate

$$
\text { flat }
$$

$1-2$

suberect to spreading

translucent green
$17-23$
19-21
5.9-6.3
12-16

\section{S. psiloclada}

glabrous

oblong

8.3-17.4

$3.9-7.5$

more or less obtuse

obtuse

scabrous above

entire

flat to convex

$$
\text { 0.3-1 }
$$

spreading to pendant

$$
1-2
$$

pink with fine red stripes

scabrous

$5.5-6.6$

obtuse

glabrous

13.4-18.1

$16.1-17.9$

$3.7-4.8$

$12.5-15.5$

\section{S. perileuca}

scabrous to hispid

broad-elliptic or oblong-elliptic

$$
\begin{gathered}
6.2-11.8 \\
2.9-4.9 \\
\text { acute } \\
\pm \text { cuneate } \\
\text { glabrous }
\end{gathered}
$$

denticulate-serrulate, hyaline slightly convex

$$
0.5-1
$$

pendant

translucent yellow-green

scabrous

8.7-10

\pm obtuse

glabrous

$12-13.8$

11.9-14.3

2.4-3 


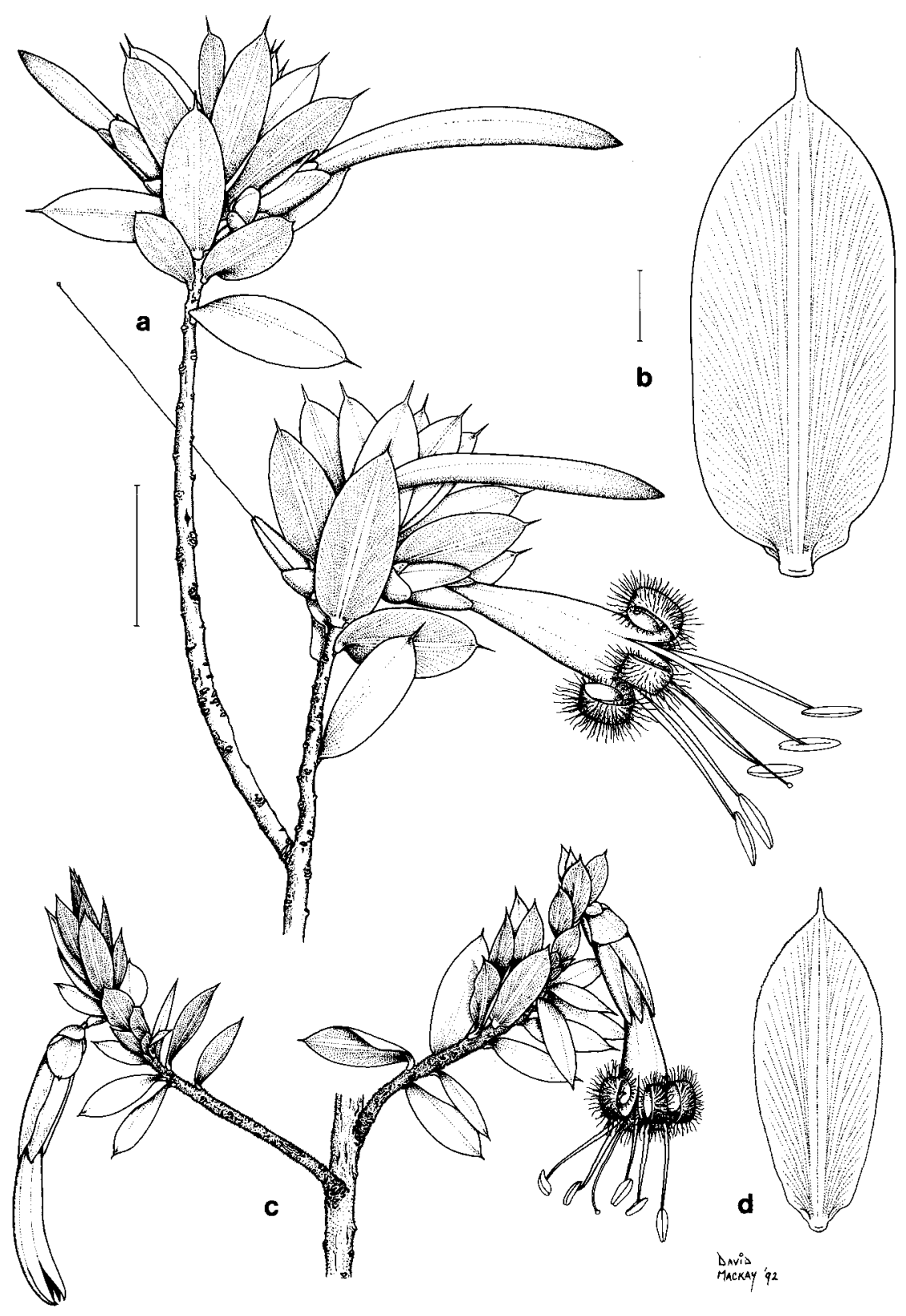

Figure 1. S. psiloclada J. Powell. a, habit; b, leaf detail (type specimen). S. perileuca J. Powell. c, habit; $d$, leaf detail (type specimen). Scale for habit $=1 \mathrm{~cm}$; scale for leaf $=2 \mathrm{~mm}$. 


\section{S. psiloclada J. Powell, sp. nov.}

A S. triflora foliis venetis brevibus late oblongis aliquantum convexis, apicibus foliorum subobtusatis atque floribus parvulis differt; a $S$. viridi ramulis glabris et floribus roseis vel carmesinis differt.

TyPE: New South WALEs: South Coast: Wadbilliga National Park, near Green Hole, N of Green Creek, c. $12 \mathrm{~km}$ ENE of Kydra, 36 25'45"S, 149 31'12"E, $1130 \mathrm{~m}$ alt., P. Beesley $349 \mathcal{E}$ D D. Binns, 27 Mar 1985 (holo CBG8502565, iso NSW, MEL; Figure 1a, b).

Erect to spreading shrub, $60-150 \mathrm{~cm}$ high; stems grey-brown, rounded, glabrous, with pale brown bark, rough and corky towards the base; branchlets brown or red-brown, slightly ribbed, glabrous. Leaves bluish or greyish green, evenly spaced, suberect to horizontally spreading, non-imbricate, spiral, oblong, rarely broadly ovate or more elliptic, 8.3-17.4 mm long, 3.9-7.5 mm wide (length:width ratio 1.9-2.8:1); apex broadly acute or obtuse, with an aristate tip $0.7-1.7 \mathrm{~mm}$ long; base obtuse; lamina flat to slightly convex and glabrous adaxially, discolorous, paler and papillose-scabrid abaxially; venation inconspicuous above, striate below with 3-5 central veins and many branches to the margin; margin very slightly recurved, entire but irregular, almost undulate towards the apex; petiole poorly developed to c. $1 \mathrm{~mm}$ long. Young seasonal growth leaves are shorter, broader, elliptic or obovate, the margin hyaline and minutely fringed overall. Flowers solitary or sometimes two together in the upper leaf axils, spreading to pendant, light pink or darker pinkish crimson outside, paler inside; peduncles 1.5-2 mm long, hispid, with a bract-like rudiment above the flower (when solitary) and 3-4 sterile bracts at the base. Bracts and bracteoles broadly ovate, subobtuse or obtuse, glabrous except for the ciliolate margins; bracts 1-1.9 mm long, 1.5-2.1 mm wide; bracteoles 2.6-3.2 $\mathrm{mm}$ long, 2.3-3.4 $\mathrm{mm}$ wide. Sepals tinged red, ovate, 5.5-6.6 mm long, 3-3.3 mm wide, obtuse, glabrous except for the ciliolate margins. Corolla tube exceeding sepals, cylindrical, $13.4-18.1 \mathrm{~mm}$ long, $4.6-4.9 \mathrm{~mm}$ wide, glabrous outside, sparsely pubescent inside and with a ring of hairs towards the base; lobes erect at the base, revolute above, $16.1-17.9 \mathrm{~mm}$ long, 2.1-2.5 mm wide, glabrous outside, inside sparsely hairy with the hairs longer over the upper half. Anthers fully exserted, $3.7-4.8 \mathrm{~mm}$ long, attached above the midpoint to the filament; filaments 12.5-15.5 mm long, glabrous. Ovary ovoid, 4-5 mm long, 3-4.2 mm wide, ridged, 5locular, glabrous; style filiform, $27.5-35.3 \mathrm{~mm}$ long, glabrous; nectary annular but readily breaking apart into scales, $1-1.2 \mathrm{~mm}$ high, with lobed upper margin. Fruit not seen.

DERIVATION OF EPITHET: From the Greek psilos, bare or smooth and clada, branches, reflecting the lack of hairs on the stems and branches.

FLOWERING PERIOD: Flowers January to March.

HABITAT: Recorded as rare or occasional in open forests dominated by Eucalyptus fastigata - E. radiata, E. fraxinoides or E. pauciflora - E. kybeanensis, on rocky ridges, steep slopes and broad gullies with well- to poorly-drained skeletal sandy soils or sandy loams over granite or other igneous rocks at 900-1300 m altitude.

Distribution: Known only from a few locations in the South Coast and Southern Tableland areas of New South Wales: the Northern Budawang Range and further south in Wadbilliga and Nalbaugh National Parks (Figure 2).

Conservation Status: Listed in Briggs \& Leigh (1988) as Styphelia sp.1 and coded as 3RC. While it is conserved in some southern New South Wales National Parks little is known of its abundance or overall distribution. 
Notes: The species belongs in section Styphelia. The pollen is periporate, scabrate and 'warty' as typical of other species within that section. The corolla hairs are unicellular, twisted and ornamented with short linear tubercles (Figure 3).

Specimens eXAmined: New South Wales: South Coast: Nalbaugh National Park, 1 km NW of Wog Wog Mt trig, Albrecht 3058, 21 Feb 1987 (MEL, NSW); ridge between White Rock and Wog Wog Mountains, Gilmour 6169, 21 Feb 1987 (CBG, NSW). Southern Tablelands: Wadbilliga National Park, Wadbilliga Fire Trail, c. 1 km E of Bunberry Ck crossing, Gilmour, 8 Mar 1983 (CBG 8313471, NSW); Wadbilliga Track near Tuross River, Hamilton, 28 Jan 1985 (CBG 8500846); Bulea Brook, Northern Budawang Range, Olsen 2459, Jan 1975 (NSW); c. 0.5 km S of Razorback Fire Trail, $14.6 \mathrm{~km}$ from junction with New England Fire Trail, Rodd 6170, Kennedy \& Whitehead, 25 Jan 1991 (NSW, MEL).

\section{Styphelia perileuca J. Pozvell, sp. nov.}

A S. triflora ramulis hispidulis, foliis brevibus aliquantum convexis, marginibus foliorum denticulato-serrulatis et albidis vel hyalinis atque floribus parvulis differt.

Type: New South Wales: Northern Tablelands: Ebor to Guyra road, $5.3 \mathrm{~km} \mathrm{NW}$ of Armidale road turnoff, J.M. Powell 4500, 3 Sep 1987 (holo NSW, iso BRI, MEL, K; Figure 1c,d).

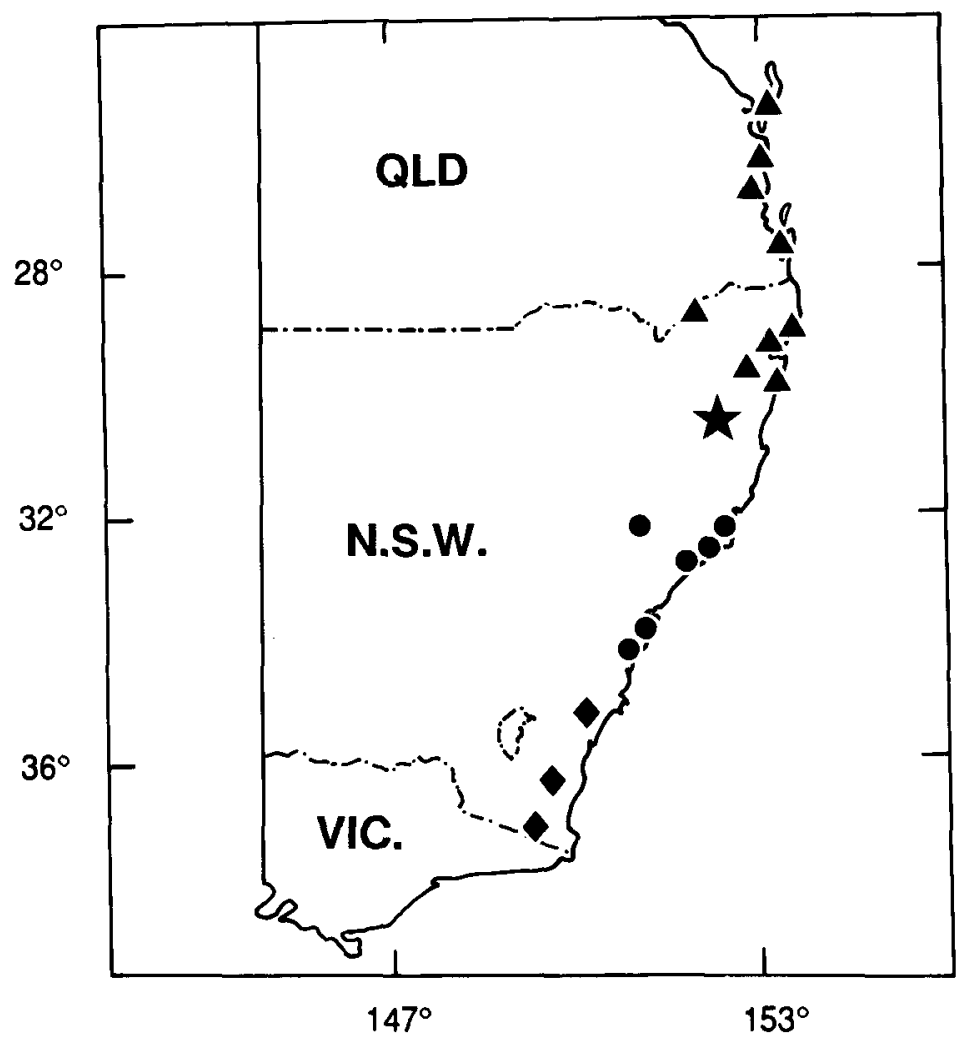

Figure 2. Distribution of S. psiloclada $(\bullet)$, S. perileuca $(\star)$ and S. viridis subsp. viridis $(\bullet)$ and subsp. breviflora (৯). 
Erect to spreading shrub 0.6-1.5-(3.3) $\mathrm{m}$ high and 1.0-3.6 m across; stems branching from the base, thin, grey-brown, rounded, glabrous, with tesselated bark; branchlets red-brown, slightly ribbed, scabrous to hispid. Leaves evenly spaced, suberect to horizontally spreading, non-imbricate, spiral, broadly elliptic or oblong-elliptic and sometimes obovate, $6.2-11.8 \mathrm{~mm}$ long, $2.9-4.9 \mathrm{~mm}$ wide (length:width ratio $=3-$ 3.3:1); apex acute, straight, with an aristate tip 0.5-0.8 $\mathrm{mm}$ long; base narrowing; lamina thick, slightly convex adaxially, concolorous or slightly paler below, the upper surface glabrous or hispidulous towards the base, the lower glabrous; venation inconspicuous above, finely multiveined below, with three central parallel veins and many branches to the margin; margin slightly recurved, denticulate-serrulate and densely so towards the apex, usually white or hyaline; petiole ill-defined, yellowish, 0.5-1 mm long, scabrous above. Young seasonal growth leaves are shorter, broader, obovate and flatter, the margins straight rather than recurved, hyaline and minutely fringed with hairs. Flowers solitary in the upper leaf axils, pendant, translucent yellow-green with fine red stripes or pale green; peduncles $3.5-5 \mathrm{~mm}$ long, hispid, with a bract-like rudiment above the flower and 4-5 sterile bracts at the base. Bracts and bracteoles broadly ovate to sub-orbicular, obtuse, apiculate, striate-veined and with the midrib thickened towards the apex, glabrous except for the ciliolate margins; bracts 1.6-2 mm long, 2.1-2.6 mm wide; bracteoles 3.1-4.5 mm long, 3.2-6 mm wide. Sepals often reddish with the margins green, ovate, $8.7-10 \mathrm{~mm}$ long, 3.3-3.9 mm wide, sub-obtuse or obtuse, apiculate, glabrous except for the ciliolate to ciliate margins. Corolla tube exceeding the sepals, cylindrical, $12-13.8 \mathrm{~mm}$ long, 3.4-5.3 mm wide, glabrous externally, sparsely pubescent inside with a ring of hairs near the base; lobes erect at the base, revolute above, 11.9-14.3 mm long, 1.6-2.6 mm wide, acute, glabrous outside, inside sparsely hairy on the lower half, the hairs becoming denser towards the apex. Anthers 2.4-3 mm long, fully exserted, attached at or above the midpoint to the filament; filaments $10.5-11.3 \mathrm{~mm}$, glabrous. Ovary ovoid 5-6 mm long, 2-3.5 $\mathrm{mm}$ wide, ridged, 5-locular; style filiform, 22-23 mm long; nectary annular, 1.4-1.6 mm high, with irregularly lobed upper margin. Fruit just exceeding the sepals, 8-11 $\mathrm{mm}$ high, 4-7 mm wide, 5-ridged, somewhat fleshy, translucent yellow-green.

Derivation of EPITHET: From the Greek peri, all round and leukos, white, referring to the white margin of the leaves.

FLOWERING PERIOD: Flowers and young fruit recorded mainly in September, December and January, with single records of buds and flowers in March and April respectively.

HАвттAт: Recorded as locally occasional in open eucalypt forests (associated with $E$. dalrympleana, E. youmanii, E. radiata) on broad ridges and gentle slopes at 1250-1500 m altitude, growing in sandy soils or light brown sandy loams over granite, and one record from heath on trachyte (J.B. Williams, pers. comm.).

Distribution: Known only from the Snowy Mountain Range and Round Mountain on the Northern Tablelands of New South Wales (Figure 2), and one record from the Lyrebird Track, New England National Park (J.B. Williams, pers. comm.).

Conservation status: This species can be classified as 2VC following Briggs \& Leigh (1988). It is known to be conserved within Cathedral Rock National Park, but its overall abundance there is low - it is locally common over only 2-3 square kilometres and absent from all other areas visited within that park and from nearby granite areas (J.B. Williams, pers. comm.).

Notes: The species belongs to section Styphelia. The pollen is periporate, scabrate and sparsely 'warty', the corolla hairs unicellular, twisted and ornamented with short linear tubercles (Figure 3). It was collected in December 1893 by J.H. Maiden and labelled as S. viridis var. breviflora on the sheet, but he noted in his report (Maiden 

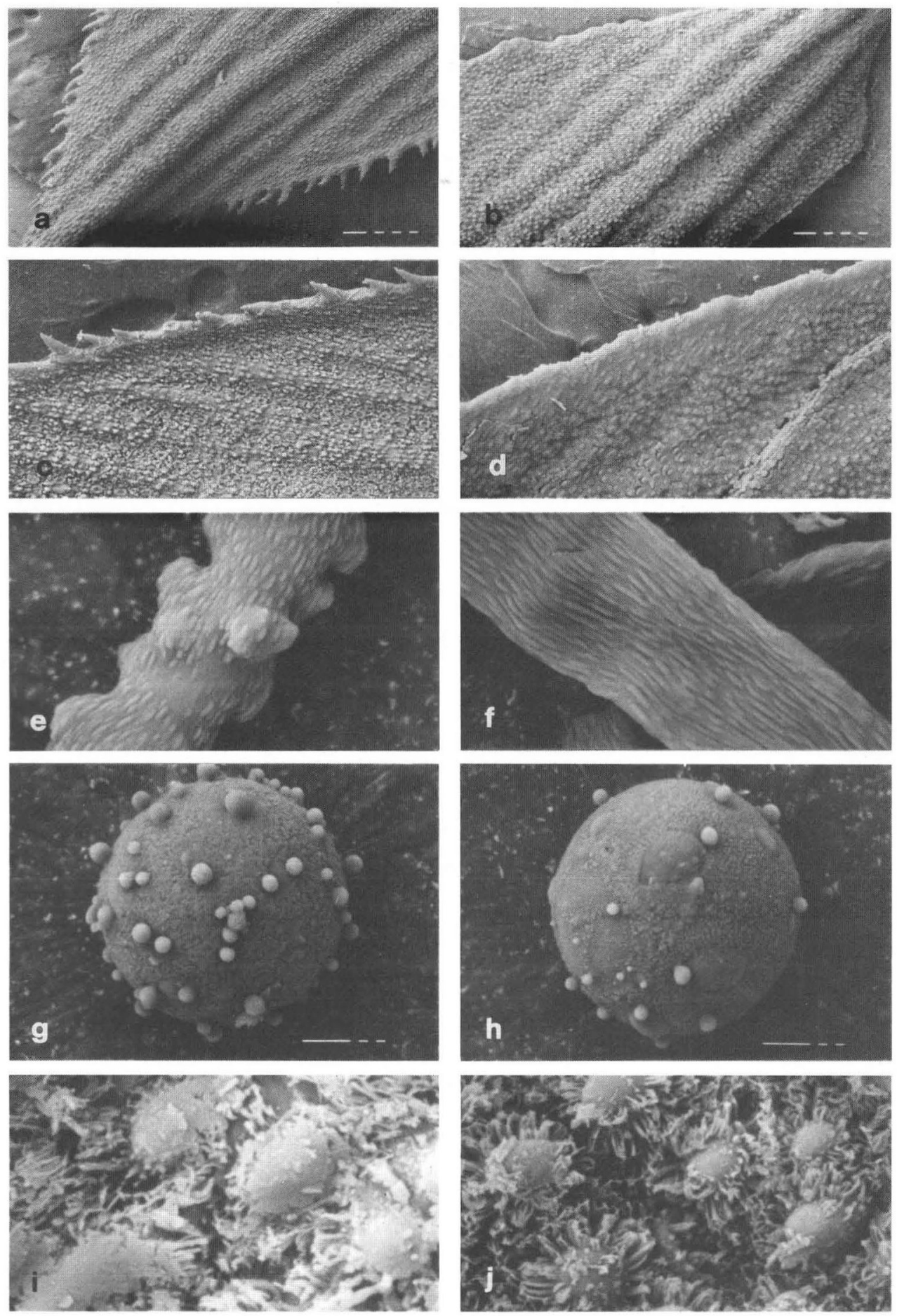

Figure 3. Scanning electron micrographs of the leaf apex, leaf margin, corolla hairs, pollen and lower leaf surface of $S$. perileuca $(\mathbf{a}, \mathrm{c}, \mathrm{e}, \mathrm{g}, \mathrm{i})$ and $\mathrm{S}$. psiloclada $(\mathbf{b}, \mathrm{d}, \mathrm{f}, \mathrm{h}, \mathrm{j}) . \mathrm{a}, \mathrm{b}$, leaf apex x 30; c,d, mid-leaf margin x 60; e,f, corolla hair x 900; g,h, pollen x 600; i,j, lower leaf surface x $1200 \mathrm{~S}$. perileuca, x 900 S. psiloclada. 
1895) 'Styphelia viridis, Andr. var., breviflora, Benth. - Guy Fawkes to Round Mountain (on the very summit). - It is not likely that Bentham's "northern parts of New South Wales" includes this sub-alpine locality in which I found it.' The species was collected again in 1968 by $\mathrm{H}$. Wissman and recognised as a distinct taxon by Wissman and J.B. Williams in April 1970, with specimens in the herbarium at the University of New England (NE) being annotated as such.

Specimens examined: New South Wales: Northern Tablelands: Round Mountain, Snowy Range, Ebor-Armidale, Burgess, 26 Sep 1972 (NSW 245925); Guy Fawkes and Round Mountain, Maiden, Dec 1893 (NSW 245929); Ebor - Guyra road, 5.3 km NW from Armidale Road turnoff, Powell 4505, 3 Sep 1987 (NSW, CANB, MEL); Snowy Mountain Range, track to Woolpack Rocks, 5 km NNE of Round Mountain, Telford 10417, 27 Sep 1987 (CBG, BRI, MEL, NSW); Cathedral Rock National Park, c. 2 km N of Cathedral Rock, Telford 10783, 2 Jan 1989 (CBG, NSW); 10 miles [16 km] WSW of Ebor and 1 mile [1.6 km] NW of Round Mountain, Williams, 26 Sep 1972 (NE 045342); Hill $0.5 \mathrm{~km} \mathrm{~N}$ of Round Mountain, c. $12 \mathrm{~km} \mathrm{~W}$ of Ebor, Williams, 14 Mar 1970 (NE 037390); near Snowy Creek, Ebor, Williams \& Wissman, 21 Oct 1969 (NE 022139); Wissman, Apr 1968 (NE 022138).

\section{Variation within Styphelia laeta R. Br.}

Bentham's (1869) treatment of Styphelia laeta as a species with three varieties has been generally accepted, but the two infraspecific taxa, var. latifolia (R. Br.) Benth. and var. angustifolia (DC.) Benth., were originally considered to be of specific rank and described as such by R. Brown (1810) and de Candolle (1839) respectively. The characters used to distinguish the taxa included leaf shape, surface flatness, and leaf margin type. Descriptions of some of the taxa included also leaf colour, leaf apex, branch hairiness, habit and flower position.

Many of these characters, together with leaf-base shape, sepal-apex shape and measurements of leaf-blade length and width, petiole length, bracteole and sepal length and hairiness, and anther and filament lengths (Figure 4) formed the basis for our reassessment of the variation within the species in the broad sense. Three specimens from Brisbane Water National Park included in S. laeta var. laeta appeared somewhat distinct in a number of attributes and were treated as a separate entity. The above characters were tabulated (Table 2). The qualitative attributes of importance in separating the taxa are branchlet indumentum and the leaf margin structure (Figures 5, 6), the adaxial leaf surface and the shape of the leaf apex and base. Discontinuities were present also in a number of the quantitative attributes. A preliminary assessment of the overall similarity of the taxa and a polygonal graph of the best discriminatory attributes suggested that $S$. laeta var. angustifolia was more distinct from both S. laeta var. laeta and S. laeta var. latifolia than they were from each other, and could warrant specific rank.

These observations were examined using PATN (Belbin 1989a, b). The data set consisted of the measurements of leaf-blade length, leaf-blade width, petiole length, sepal length, bracteole length and the angle subtended by the leaf apex (Figure 4) from 35 specimens.

The classification analysis indicated four groupings. The group 'statistics' (GSTA) showed that leaf-blade width separated the var. angustifolia taxon completely from the other three groups and var. latifolia from the other two groups. The leaf-apex angle and bracteole length both partly separated the groups although the ranges overlapped. Sepal length and blade length separated the Brisbane Water taxon from the other three groups. The ordination confirmed the presence of four groups and the distinctiveness of both the var. angustifolia and the Brisbane Water specimens. 

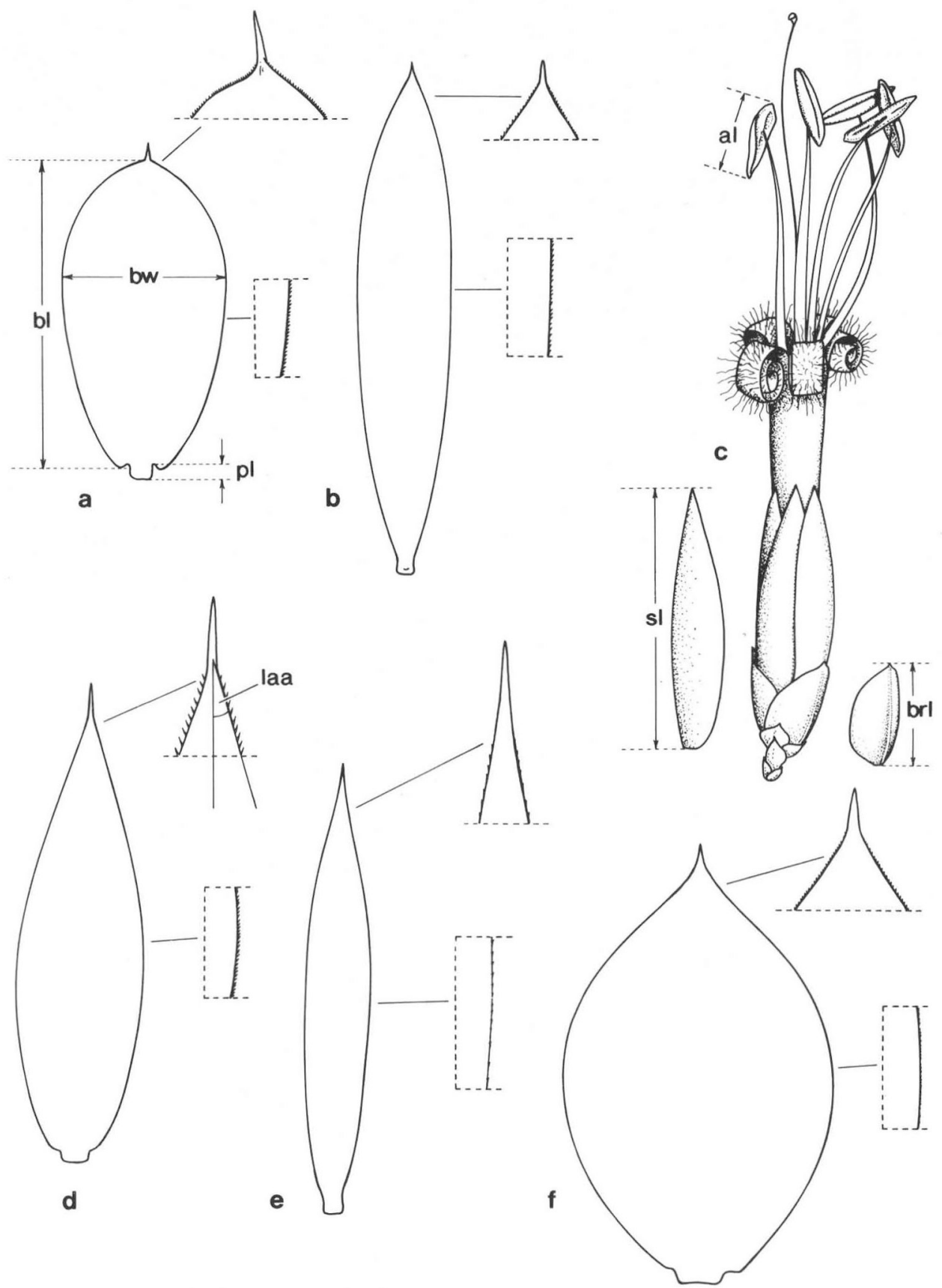

Figure 4. Attributes of Styphelia studied and measured. a, S. viridis subsp. viridis; b,c, S. viridis subsp. breviflora; $\mathbf{d}$, S. laeta subsp. laeta; e, S. angustifolia; $\mathbf{f}$, S. laeta subsp. latifolia; bl: blade length; bw: blade width; pl: petiole length. al: anther length; sl: sepal length; brl: bracteole length; laa: leaf apex angle. 
Table 2. Comparison of attributes of taxa within Styphelia laeta

\section{Character}

Branchlet indumentum

Leaf shape

Leaf margin

No. teeth/mm margin

mean

Leaf-blade length $(\mathrm{mm})$

Leaf-blade width (mm)

Leaf length:width ratio

Leaf apex

Leaf-apex angle

Leaf indumentum

adaxial surface

Leaf base

Petiole length $(\mathrm{mm})$

Bracteole length ( $\mathrm{mm}$ )

Sepal length $(\mathrm{mm})$

Sepal apex

Sepal margin

Sepal indumentum var. laeta

sparsely velutinous
elliptic to ovate-elliptic
denticulate-ciliolate

$$
\begin{gathered}
9-17(-34) \\
14.8
\end{gathered}
$$

$17.4-24.3$

$5.0-7.2$

$2.5-3.8$

acute-acuminate

$$
32-48
$$

scabridulous

truncate

$$
0.5-1
$$$$
\text { 2.3-4 }
$$$$
\text { 8.5-10.5 }
$$

acute-obtuse

ciliate

glabrous to pubescent

\section{var. laeta}

(Brisbane Water)

velutinous
narrowly ovate-elliptic
ciliolate
$10-24$
15.2
$27.9-31$
$6.5-7.5$
$4-4.3$

acuminate

21-37

hispidulous or tuberculate

$$
\text { truncate }
$$

$0.5-1.2$

$4.2-6.5$

$12.3-15.5$

acute

ciliolate

pubescent

\section{var. latifolia}

woolly

ovate

fine-ciliolate

22-35

27.2

$15.8-24.8$

$8.8-11.3$

1.6-2.4

cuspidate-acute

45-75

tuberculate

truncate

$0.5-1.2$

4-5

10-12.5

acute

ciliate overall or towards apex

glabrous or antrorse

pubescence at apex

\section{var. angustifolia}

densely velutinous

elliptic

sparsely denticulate-serrulate

$$
\begin{gathered}
3.6-7.8 \\
5.1 \\
18.9-25.1 \\
2.7-4.5 \\
3.8-8.3
\end{gathered}
$$

narrow-acute

$$
14-27
$$

scabrous at midline

$$
\pm \text { cuneate }
$$$$
\text { 0.5-2 }
$$$$
\text { 3-4 }
$$

8.5-11.5

acute-obtuse

\pm glabrous or very sparse-ciliolate

glabrous, tip pubescent 

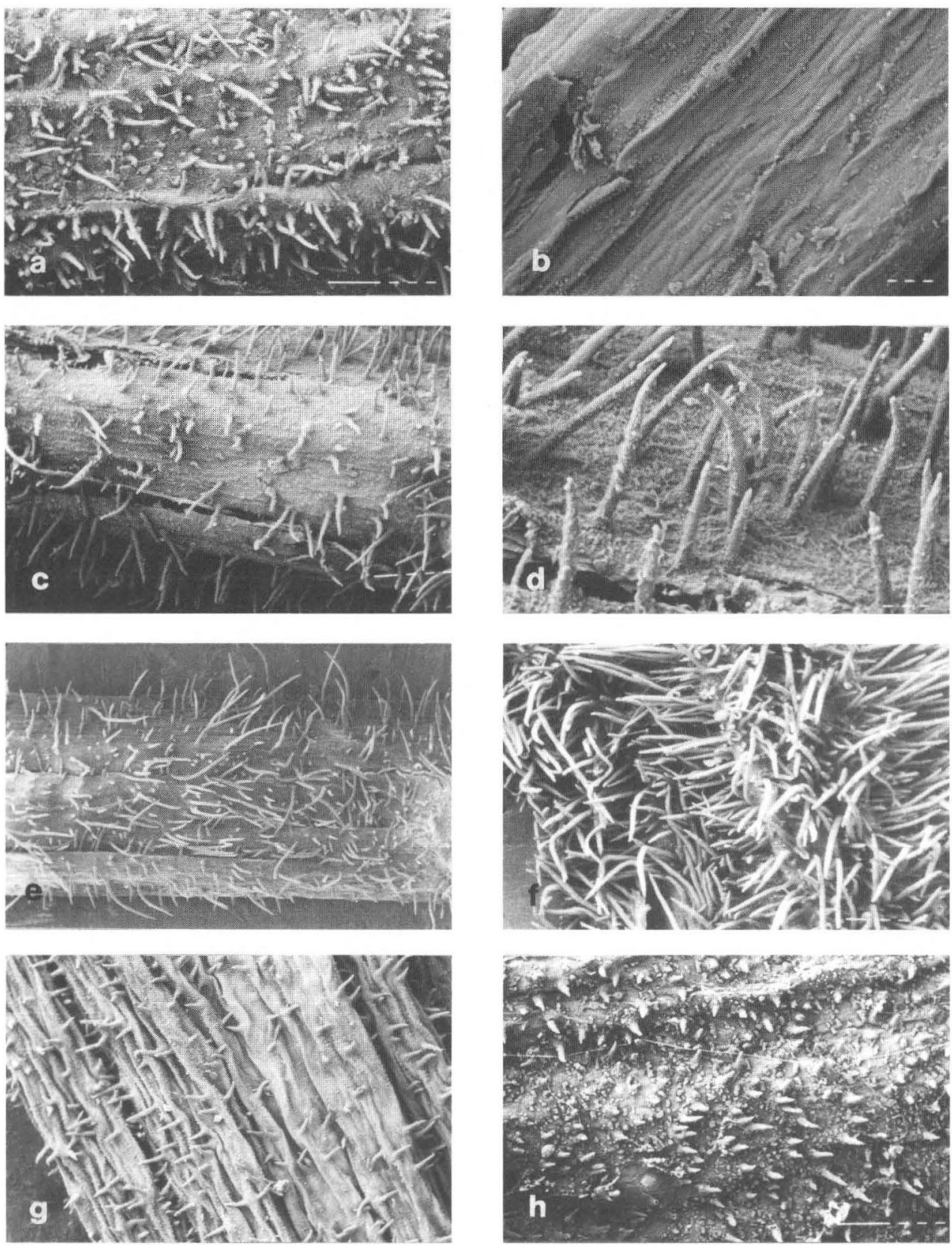

Figure 5. Scanning electron micrographs of branchlets hairs of Styphelia. $\mathbf{a}$, S. perileuca $\times 60 ; \mathbf{b}$, S.psiloclada $\times 120 ; \mathbf{c}, \mathbf{d}$, S. laeta subsp. laeta $\times 30, \times 150 ; \mathbf{e}$, S. angustifolia $\times 30 ; \mathbf{f}$, S.laeta subsp. latifolia $\times 30 ; \mathrm{g}$, S. viridis subsp. breviflora $\times 60 ; \mathbf{h}$, S. viridis subsp. viridis $\times 60$. 

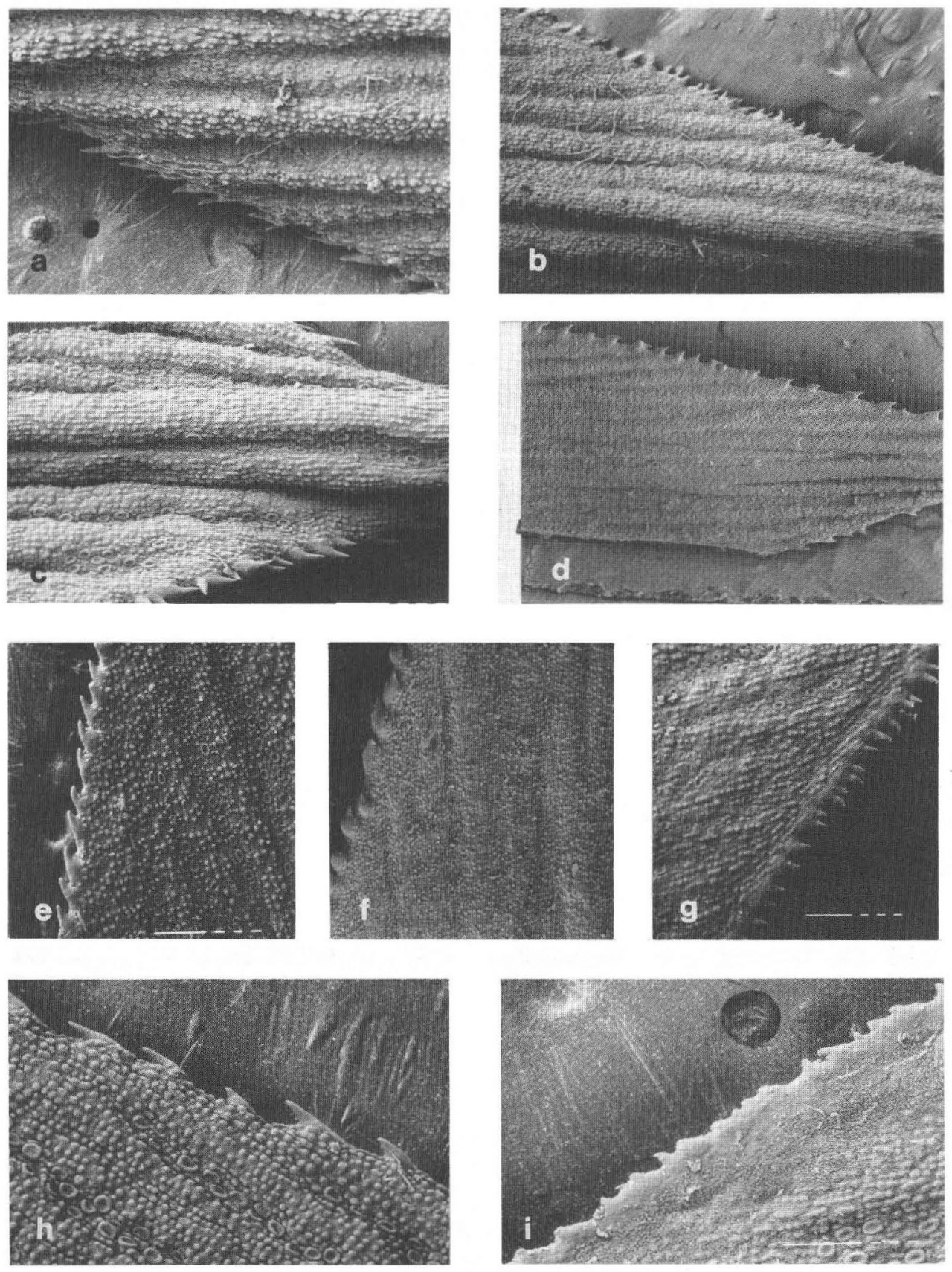

Figure 6. Scanning electron micrographs of the leaf apex margin (a-d) and mid-leaf margin (ei) of S. laeta subsp. laeta (a $\times 60$, e $\times 60$ ); S. laeta subsp. latifolia ( $\mathrm{b} \times 30, \mathrm{~g} \times 60$ ); S. viridis subsp. breviflora (c $\times 60, \mathrm{~h} \times 60)$; S. angustifolia $(\mathrm{d} \times 30, \mathrm{f} \times 60$ ) and S. viridis subsp. viridis ( $\times 60$ ). 
a
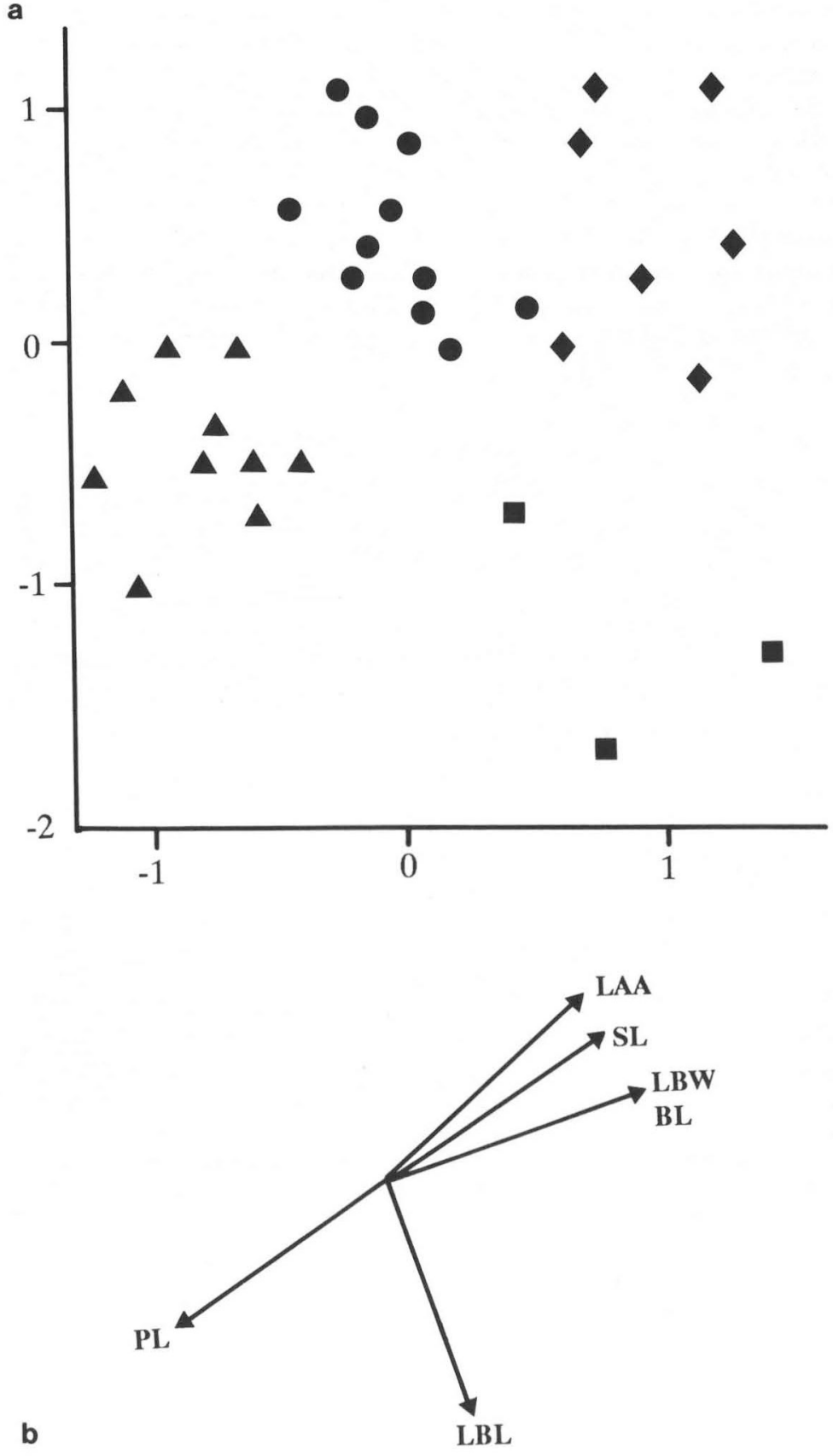

Figure 7. Morphometric analysis of Syphelia laeta. a, scatter diagram of ordination of S. laeta and S. angustifolia specimens. S. laeta subsp. laeta $(\bullet)$, Brisbane Water National Park specimens $(\boldsymbol{\square}), S$. laeta subsp. latifolia $(\bullet)$, S. angustifolia $(\mathbf{\Lambda})$; b,vectors showing direction of maximum linear correlation between each of the six attributes and the ordination space. LBL: leaf-blade length; LAA: leaf-apex angle; LBW: leaf- blade width; BL: bracteole length; SL: sepal length; PL: petiole length. Note that the vectors for leaf-blade width and bracteole length have the same direction. 
The groups resulting from the analyses (Figure 7) correspond well to the taxa defined previously and support our earlier conclusions based on both qualitative and quantitative measures. We consider that var. angustifolia warrants specific rank (because of its distinct morphology and distribution), but var. laeta and var. latifolia should be treated as subspecies; they have a number of morphological attributes that show overlapping ranges, but appear to be ecologically, if not geographically distinct. The Brisbane Water specimens differ from the other material studied in leaf-blade length, sepal length, in the adaxial leaf surface sometimes being hispidulous (two specimens out of three) and the margin ciliolate rather than denticulate-ciliolate; they appear to represent a new taxon, but further material is needed for study before their status can be determined. Because of recent devastating fires in the area it has not been possible to obtain further collections.

\section{Ecological notes}

The S. laeta subspecies are probably parapatric if not sympatric, while $S$. angustifolia is parapatric or allopatric with them. S. laeta subsp. laeta is found in the Sydney region and the lower Blue Mountains (Central Coast and Central Tablelands), growing in the understorey of open dry sclerophyll forest on sandstone. It flowers between February and August but mainly in March and May. Its conservation status is 2RC; it is conserved in Brisbane Water National Park and Yengo National Park and has been recorded recently from the Cumberland Plain Woodlands and Castlereagh Woodlands as well as Hawkesbury Sandstone areas (Benson \& McDougall 1991). S. laeta subsp. latifolia is found north of the Hawkesbury River from Mt White north to Ourimbah and west to Kulnura (Central Coast), and has been recorded also from the North Western Slopes at Warialda. It grows in open sites in mixed shrublands, on the margins of low open eucalypt woodland or swamps and appears to be tolerant of some disturbance. It flowers between March and June. Its conservation status is 3RC; in the Mt White to Kulnura area it is locally common but vulnerable as it often grows on the road margins; it is conserved in the Brisbane Water National Park.

Styphelia angustifolia is found at lower elevations in the Blue Mountains (CC) and has been collected also from Pigeon House Range in the Southern Tablelands and from Warialda (North Western Slopes). It is found in open rocky areas in open sclerophyll forest. Flowers are recorded in July, August, November and December, with fruit recorded in April, May and August. Its conservation status is $3 \mathrm{~V}$ ? ; the lack of recent collections suggest that the species is now rare; it is possibly conserved in Morton National Park.

The single specimen records from Warialda for S. laeta subsp. latifolia and for S. angustifolia require field investigation as they indicate a very considerable disjunction in the distribution range of each taxon.

\section{Nomenclatural notes}

\section{S. laeta $R$. Br.}

(Brown 1810: 537).

TYPE CITATION: '(J.) v.v.'

LECTOTYPe (here designated): New SOUtH WALES: in sylvis prope Parramatta versus Sydney, R. Brown (Bennett No. 2395), desc 23 May 1802, 'Styphelia glauca Nob' (BM); isolectotype NSW. The typed label of the lectotype has the date of the collection as 19 May 1802. The date of 23 May 1802 in Brown's hand refers to the description, as 'desc' precedes the date. Another sheet at BM has 'Port Jackson' in Brown's hand. 
Two subspecies are recognised:

\section{S. laeta $R$. Br. subsp. laeta}

TYPE: as cited above.

IlleGitiMATE NAME: S. laeta R. Br. var. typica Domin (Domin 1928: 1050); this is the type variety, S. laeta $R$. Br. var. laeta.

Selected specimens eXAmined: New South Wales: Central Coast: Londonderry Road near Rickabys Creek, Burgess, 4 Dec 1962 (NSW 143347); Blakehurst, Camfield, Apr 1893 (NSW 246705); Dural, Debenham, Apr 1959 (NSW 246702); Brisbane Water National Park, Fallding \& Benson, 3 May 1979 (NSW 246699); Warrah to Patonga track, Fallding \& Benson, 23 May 1979 (NSW 246701); Revesby to Georges River, Foster, 9 Apr 1956 (NSW 36659); Mellong Range; 1 mile [1.6 km] N of Grassy Hill, Johnson, 9 Apr 1953 (NSW 23446); Yerrinbool, Johnson 15 Apr 1951 (NSW 143344); Bucketty, 12 miles [c. $19 \mathrm{~km}$ ] by road north west from Kulnura, McGillivray 1243, 5 July 1965 (NSW); Lawson Ridge Road, Powell 420, 6 Dec 1975 (NSW); Lawson area, Reilly, 11 Nov 1975 (NSW 246704); Pearl Beach, Whaite 688, 31 May 1950 (NSW).

S. laeta $R$. Br. subsp. latifolia (R. Br.) J. Powell, comb. et stat. nov.

BASIONYM: Styphelia latifolia R. Br. (Brown 1810: 537).

TYPE CITATION: '(J.) v.v.'

Lectotype (here designated): New South Wales: Banks of the Hawkesbury [River], $R$. Brown (Bennett No. 2398), [1802-5], (BM).

SYNonym: S. laeta R. Br. var. latifolia (R. Br.) Benth. (Bentham 1869: 147).

The lectotype has mature and old flowers present. Another sheet at BM has a typed label 'Brown, 19 May 1802, Banks of Hawkesbury river'; the specimen has old flowers only, but may be an isolectotype.

Notes: Bentham (1869) in reducing S. latifolia to varietal level stated 'Var. latifolia Leaves short, very broadly ovate and very concave - S. latifolia, $\mathrm{R}$. Br. Prod. 537; ... - Hawkesbury river, R. Brown.'

SPECIMENS EXAmined: New South Wales: Central Coast: Girrakool, Brisbane Water National Park, Bishop 226 \& Gunnell, 10 June 1984 (NSW); Ourimbah State Forest, de Beuzeville, Apr 1918 (NSW 35709); Somersby, Fallding, 30 Mar 1979 (NSW 245291); Lake Womberall, Fletcher, Aug 1888 (NSW 245281); Point Clare [Gosford], Forsyth 23 June 1897 (NSW 35633); 3 miles [c. $5 \mathrm{~km}$ ] north of Kulnura store, Foster, 26 Apr 1956 (NSW 36656); 7 miles [c. $11 \mathrm{~km}$ ] south of Central Mangrove, Foster, 26 Apr 1956 (NSW 35633); Kulnura, Johnson, 29 June 1954 (NSW 154799); 3 miles [c. 5 $\mathrm{kml}$ north of Peats Bridge, Salasoo, 20 July 1969 (NSW 245286). North West Slopes: Warialda, McCusker, June 1957 (NSW 245288).

\section{S. angustifolia $D C$.}

(Candolle 1839: 735).

TYPe CITATION: 'St. laeta Sieb.! pl. exs. n. holl. n. 79 non Brown'.

TYPE: Sieber $n .79$ (holo G-DC; iso BM).

Synonym: S. laeta var. angustifolia Benth. (Bentham in Endlicher 1837). Type CITATION: 'Styphelia laeta Sieb. Pl. Nov. Holl. exs. n. 79 est ejusdem varietas angustifolia'.

Specimens examined: New South Wales: Central Coast: [Royal] National Park, Betche, Dec 1889 (NSW 35704); Loftus, Camfield, May 1899 (NSW 35705), Aug 1897 (NSW 35706); Hill Top, Cheel, 10 Nov 1923 (NSW 245202); Rocky Creek, near Hill Top, Cheel, Jan 1912 (NSW 245206); Valley 
Heights, Fletcher, -, (NSW 245198); Falconbridge, Fletcher, 29 Dec 1886 (NSW 35703); Linden, Hamilton, Jan 1915 (NSW 237906). Southern Tablelands: c. 1 mile [1.6 km] east of Endrick River on road from Braidwood to Nowra, Hoogland 11370, 4 Feb 1968 (NSW). North West Slopes: Warialda, Boorman, July 1905 (NSW 143343), Paterson, 10 Aug 1958 (NSW 245204).

\section{Status of Styphelia laeta R. Br. var. glabra R. Baker}

(Baker 1896: 456).

TYPE: 'Camboon; October.' Baker states 'I am in doubt about the specimens placed here under a new variety, but I prefer this to proposing a new species. The flowers are red, the sepals acute, and the leaves narrow-lanceolate, - characters not included under Bentham's description of the species'. The specimens were collected 'during the months of September, October, November and December, in the years 1895, 1893, 1892 and 1890 respectively ...'

Three sheets of specimens collected by R.T. Baker at Camboon in September and October, 1893 are lodged at NSW; they have been re-determined as Styphelia triflora Andr. They have the glabrous branchlets, glabrous leaves, entire leaf margins, cuneate leaf base and more or less distinct petiole characteristic of this species.

\section{Variation within Styphelia viridis Andr.}

This species was described and illustrated by Andrews (1803) using a cultivated plant as his basis. Robert Brown (1810) used the name S. viridiflora R. Br. for the same species and referred to Andrews' publication as well as his own specimens. Brown's name, although more appropriate for this green-flowered species, is superfluous.

Bentham (1869) described a new variety, S. viridis Andr. var. breviflora Benth. This variety had 'leaves narrower. Sepals more obtuse, about 4 lines [8 $\mathrm{mm}$ ] long. Corollatube about $1 / 2$ in. [12 mm] long'. He noted that 'To this belong the specimens from Queensland and from the northern parts of N. S. Wales'.

Stanley \& Ross (1986) in their treatment for the Flora of SE Queensland place S. viridis var. breviflora Benth. in synonymy under $S$. viridis Andr. stating that 'a few specimens with short obtuse sepals and short corolla tube have been called $S$. viridis var. breviflora Benth. but there is no apparent discontinuity in the population to justify varietal status for them.'

Specimens held at NSW under the name S. viridis Andr. exhibit considerable variation in the shape of the leaf-blade, apex and base, in petiole length and in corolla lobe length: tube length ratios. Measurements and descriptions of the following attributes were tabulated as a basis for re-assessment of taxa within the species: leaf blade length and width, length of petiole, bracteole, sepal, corolla-tube and -lobe, anther and filament, and the overall shape of the leaf, its apex and base (Table 3 ). The qualitative attributes that separate the taxa were mainly the shape of the leaf-blade and the leaf base, the branchlet indumentum (Figure 6) and to some extent the leaf apex and margin (Figure 7). In quantitative attributes the variation appeared at least partly discontinuous in leaf blade length, blade width, petiole length, sepal length and anther length and these attributes were used in the morphometric analyses.

Data from 44 specimens were analysed using PATN. The resultant classification indicated the presence of two groupings and separated the Central Coast and near North Coast specimens from those found on the far North Coast and in Queensland. The group 'statistics' (GSTA) indicated that it was a combination of attributes that separated the taxa, the most important being petiole length, sepal length, anther length, 

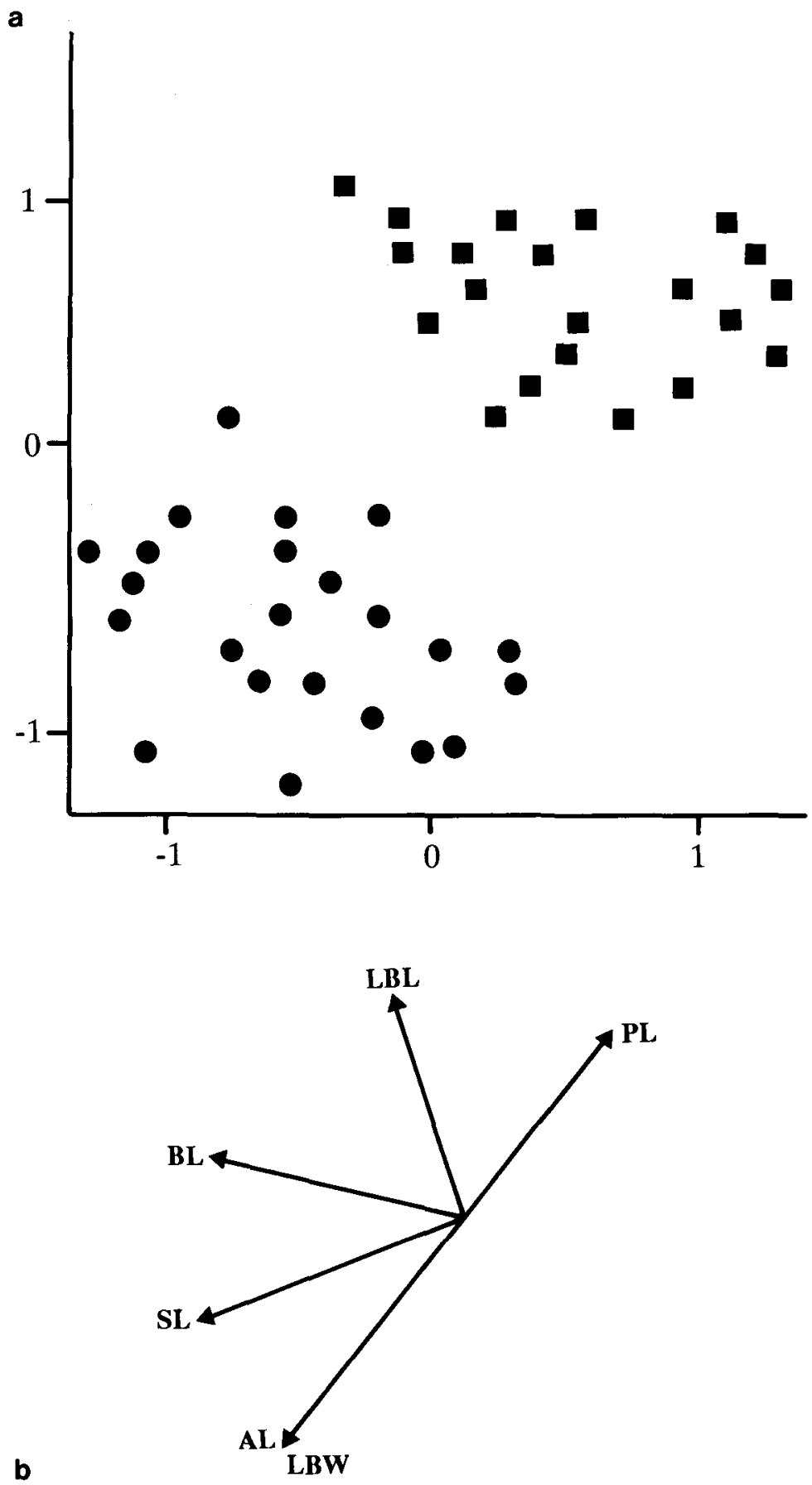

Figure 8. Morphometric analysis of Styphelia viridis. a, scatter diagram of ordination of S. viridis subsp. viridis $(\bullet)$ and subsp. breviflora $(\mathbf{0}) ; \mathbf{b}$, vectors showing direction of maximum linear correlation between each of the six attributes and the ordination space. LBL: leaf-blade length; PL: petiole length; AL: anther length; LBW: leaf-blade width; SL: sepal length; BL: bracteole length. Note that the vectors for leaf-blade width and anther length have the same direction. 
and leaf-blade width. The ordination (Figure 8) confirmed the presence of the two groups and their relative distinctiveness.

Given that the ranges of many of the morphological attributes overlapped it was concluded that the two taxa distinguished should be treated as subspecies. Study of the specimens from Queensland regions showed that they belonged to subsp. breviflora. The name 'breviflora' is somewhat inappropriate as corolla tube lengths in the two taxa overlap to a considerable extent (Table 3). However, Bentham's description is correct with regard to the leaves being narrower and the distribution of the taxa.

\section{Ecological notes}

The subspecies appear to be allopatric. S. viridis subsp. viridis is found on the Central and near North Coast of New South Wales in coastal scrub-heath and in the understorey of open forest and woodlands on sandy soils over sandstone. It flowers between April and August. Its conservation status is $3 \mathrm{RC}$; it is locally common but widespread habitat destruction in recent years makes it vulnerable. S. viridis subsp. breviflora occupies much the same habitat on the far North Coast of New South Wales and extends into Queensland as far north as Fraser Island. It is found in coastal scrubheaths, on sand dunes with open forests of Angophora costata and Eucalyptus pilularis. It flowers mainly between May and July and occasionally also in September. This subspecies appears to be adequately conserved in National Parks in New South Wales and Queensland.

Table 3. Comparison of attributes of taxa in S. viridis

\author{
Character \\ Leaf shape \\ Leaf-blade length $(\mathrm{mm})$ \\ Leaf-blade width $(\mathrm{mm})$ \\ Leaf length:width ratio \\ Leaf apex \\ Leaf base \\ Petiole length $(\mathrm{mm})$ \\ Bracteole length $(\mathrm{mm})$ \\ Sepal length $(\mathrm{mm})$ \\ Corolla-tube length $(\mathrm{mm})$ \\ Corolla-lobe length $(\mathrm{mm})$ \\ Anther length $(\mathrm{mm})$ \\ Filament length $(\mathrm{mm})$
}

\section{var. viridis}

oblong to oblong-obovate

$14.8-22.4$

4.7-7.2

2.3-4. 1

broadly acute to obtuse

obtuse

0.5-1.1

3.6-4.8

12.4-18

$16-21.5$

13.5-18

4.8-6.8

9.5-17.5 var. breviflora

oblong to oblong-elliptic

19.6-25.6

2.9-4.9

4.5-7.3

acute to broadly acute narrowing

1.0-2.1

3-5

8.5-13.3

14-23

12-16

3.2-4.5

10-16 


\section{Nomenclatural notes}

S. viridis $A n d r$.

(Andrews 1803: t. 312)

TYPE CITATION: 'Our figure was taken from a plant in the Hibbertian collection, in the month of April, 1803.'

Stafleu \& Cowan (1976) suggest that the text was 'probably written by John Kennedy', but Andrews is the botanical artist and engraver and is generally accepted as the author.

SYNONYM: S. viridiflora R. Brown (Brown 1810: 537). TYPE CITATION: '(J.) v.v.'

Lectotype (here designated): New SOUth WALEs: Port Jackson, R. Brown (Bennett No. 2396), [17 May 1802], (BM); isolectotype NSW. The specimen is in flower. A second $\mathrm{BM}$ sheet has the same annotation.

Two subspecies are recognised:

S. viridis Andr. subsp. viridis

TYPE: as cited above.

Specimens eXamined: New South Wales: North Coast: Port Stephens, Boorman, May 1912 (NSW 143359); Tuncurry State Forest, Burgess, 22 June 1961 (NSW 241789); Tuncurry, Cheel, 11 May 1925 (NSW 241787); Seal Rocks, Fox 7907039, 7 July 1979 (NSW), Tate, 6 Aug 1977 (NSW 241785); Nelson Bay, Lithgow 156, 10 May 1965 (NSW); Tomago sandbeds, McDonald 23 Aug 1966 (NSW 241791); Belmont, McReadie, June 1961 (NSW 241790). Central Coast: Kurnell, Boorman, May 1906 (NSW 241783); La Perouse, Camfield, July 1898 (NSW 143360); Coveny 11129 \& J. Thomas, 7 July 1982 (NSW); Lady Robinson Beach, Fletcher, 30 Apr 1887 (NSW); Rose Bay, Helms, 22 June 1901 (NSW); Vaucluse to Bondi, Maiden Aug 1887 (NSW 241778); Port Jackson district, Maiden, July 1896 (NSW 35717); Bundeena, Oxenford, 16 May 1948 (NSW 35719); Waterfall, G. Rodway, 23 July 1933 (NSW 241782); Port Hacking, Whaite 1178, 9 Aug 1952 (NSW).

S. viridis $A n d r$. subsp. breviflora (Benth.) J. Powell comb. et stat. nov.

BAsIONYM: S. viridis Andr. var. breviflora Benth. (Bentham 1869: 148), as 'Var. ?breviflora.'

TYPE CITATION: 'To this belong the specimens from Queensland and from the northern parts of N.S. Wales'. Queensland specimens cited under the name S. viridis included 'Morton island, F. Mueller' and 'Darling Downs, F. Law'. The other specimens cited belong to the type subspecies.

LECTOTYPE (here designated): QUEENSLAND: Moreton Island, F. Mueller (MEL 226791); isolectotype $\mathrm{K}$.

Specimens EXAmined: New South Wales: North Coast: 3 km west of Red Rock, Foreman 937, 24 Aug 1985 (MEL); Bunjalung National Park, Powell 4529, 4 Sep 1987 (NSW), Powell 4593, 1 May 1989 (NSW); Coaldale Road, Powell 4587, 1 May 1989 (NSW); Diggers Camp, Powell 4551, 5 Sep 1987, (NSW); 9 km NE of Evans Head, Broadwater National Park, Powell 4602, 2 May 1989 (NSW). Queensland: Moreton: Nambour, Ward, July 1964 (NSW 241795); Stradbroke Island, White 1701, July 1922 (NSW, BRI, MEL). Wide Bay: 22 miles [c. $35 \mathrm{~km}$ ] E of Gympie, Smith 12111, 12 May 1964 (BRI, NSW); Cooloolah sand hills, Thorne 21292, Coaldrake \& Ridley, 18 May 1959 (BRI, NSW); Fraser Island, Willis, Aug 1953 (NSW 241794). 


\section{Acknowledgements}

We should like to thank Barry Conn for photographing Styphelia types at the Natural History Museum, London, Surrey Jacobs for comment on the manuscript, John Williams for helpful discussion, Peter Wilson for checking the Latin, Tony Martin for assistance with the scanning micrographs, and David Mackay for the line drawings. We are grateful to the Directors of Herbaria in Melbourne, Canberra and Brisbane for the loan of specimens.

\section{References}

Andrews, H.C. (1803) The botanist's repository for new and rare plants, vol. 5 (Bensley: London). Baker, R. (1896) On the botany of Rylstone and the Goulburn River districts. Proc. Linn. Soc. N.S.W. 21, Part I: 427-466.

Belbin, L. (1989a) Technical reference PATN pattern analysis package (CSIRO: Canberra).

Belbin, L. (1989b) Users guide PATN pattern analysis package (CSIRO: Canberra).

Bentham, G. (1869) Flora Australiensis, vol. 4 (L. Reeve \& Co.: London).

Benson, D. \& McDougall, L. (1991) Rare bushland plants of western Sydney (Royal Botanic Gardens: Sydney).

Briggs, J.D. \& Leigh, J.H. (1988) Rare or threatened Australian plants. Australian National Parks \& Wildlife Service Special Publication no. 14.

Brown, R. (1810) Prodromus Florae Novae Hollandiae et Insulae Van Diemen, vol. 1 (J. Johnson \& Co.: London).

Candolle, A.P. de (1839) Prodromus systematis naturalis regni vegetabilis (Treuttel \& Wurtz: Paris).

Domin, K. (1928) Beiträge zur Flora und Pflanzengeographie Australiens. Bibliotheca Botanica, 89(VI): 479-574.

Endlicher, S.L. (1837) Enumeratio plantarum quas in Novae Holandine ora austro-occidentali ad fluvium Cygnorum et in Sinu Regis Georgii collegit Carolus Liber Baro de Hugel (Fr. Beck: Vienna).

Maiden, J.H. (1895) The Dorrigo Forest Reserve Part II - A list of the plants collected, with descriptive notes of those of economic or botanical interest. Agricultural Gazette of N.S.W. 5 : $599-633$.

Mueller, F. (1867) Fragmenta phytographiae Australia, vol. 6 (Government Printer: Melbourne).

Mueller, F. (1889) Second systematic census of Australian plants Part I - Vasculares (McCarron Bird: Melbourne).

Stafleu, F.A. \& Cowan, R.S. (1976) Taxonomic Literature edn 2, vol. 1. (Bohn, Scheltema \& Holkema: Utrecht).

Stanley, T.D. \& Ross, E.M. (1986) Flora of south-eastern Queensland, vol. 2. (Queensland Dept. of Primary Industries, Brisbane, Misc. Publ. QM84007).

Manuscript received 26 November 1991

Manuscript accepted 15 July 1992 